\title{
Education of counsellors and therapists for the work with the topic of holes in roles
}

\author{
Gabriela Slaninova $^{1 \mathrm{a}}$, Lucie Vokalova ${ }^{1}$ \\ ${ }^{1}$ University of Hradec Kralove, Faculty of Education, Department of Social Pedagogy, Rokitanskeho \\ 62, 50003, Hradec Kralove, Czech Republic
}

\begin{abstract}
The article focuses on the education of counsellors and therapists for the work with the topic of holes in roles. It uses pieces of knowledge of contemporary approaches in counselling and psychotherapy. It defines holes in roles on the theoretical and practical level, introduces an original and specific approach to its processing and skills of a helping worker, which he/she gains by theoretical and practical education. Assuming the perspective of Pesso Boyden System Psychomotor we treat the deficits in basic developmental needs in the context with holes in roles. These include the needs of place, nurturance, support, protection and limits. Deficit in the need for place is a result of being refused by the first carer - the individual desires to belong somewhere but $\mathrm{s} / \mathrm{he}$ cannot find his/her place. The consequences of a lack of saturation are the dependence on the presence and actions of another, feelings of inner emptiness and the inability to express one's needs. Insufficient support leads to feelings of uncertainty, unease, weak self-confidence and self-respect and the tendency to underestimate oneself, feeling weak and incompetent. A deficit in protection brings the feelings of helplessness, the individual is oversensitive, vulnerable and full of anxiety. Insufficient limits cause the tendency towards destructivity and the inability to differentiate between reality and fantasy.
\end{abstract}

Keywords: Counsellor; therapist; holes in roles; movies

\section{Introduction}

In Pesso Boyden therapy there are reflected psychoanalytic and family oriented principles and a reflection of client-oriented approach, $[4,5]$. As a reference of psychoanalytic principles there is a special consideration to figures from early childhood and their inner representations, which are involved in futher formation of individual's formation.

\footnotetext{
a Corresponding author: gabriela.slaninova@uhk.cz
} 
Furthermore selected elements and assumptions consistent with PBSP that can be found in objectively relational schools, ego psychology, and self-psychology, [4, 6].

PBSP shares the view with ego psychology, that memory is congenital. In addition ego psychology considers perception and motor coordination as congenital. During personality development it can be applied as a primary driving force of the ego to adapt and to control objective reality. It follow that the ego has its own energy and developmental tendencies, it is involved in the process of maturation and it is not just a result of conflicts in the context of sex and aggression. There is also a certain emphasis on later life stages during the personality development and psychopathology, not only at the certain stages. The key topics for ego psychology are issues concerning identity, intimacy and ego's integrity. The ego is considered to be the main organizing principle; attention is paid to the basic trust, autonomy and initiative, [3].

Theory of object relations shares with PBSP the highlighting of the relationship meaning between Self and objects, (these are considered by theoretic of object relations as for the main principle influencing human life.). Object relations as intrapsychic structures are effected by early interpersonal relations and significantly interfere into future interpersonal relationships. They represent mental representations Self and others (objects), [3].

One of the main topics of PBSP is holes in roles. Pesso, [9] talks about holes in roles in the context of family relationships network. The role gaps occur where intergrality should exist. They evoke a feeling of imperfection and incompleteness, resulting in natural tendency to do something what would fill the gap and the unit was complete again. The aim is to experience enclosure and completion. Pesso builds on his own experience from a longstanding practice and emphasis that an individual is born with $\mathrm{s}$ genetically built internal model. Providing the ability to recognize and automatically (intuitively) respond to relative or next of kin, whom he/she meets during life (during development).

Another innate ability is taking on self and to perform all roles - according to current family situation, where we are brought up, [8]. One is born with an inner knowledge of a role of a mother, a father, grandparents, an aunt, an uncle, sibling... Regardless of gender he/she is able to act (in other words take on a role) like a mother, a father, etc. Pesso [8] speaks in this context about "stem selves" - filling up the gap by self. Can be developed by conditions and requirements of the environment. For example a small child knows, that his/her parents were refused by their parents and wishes for them better care - implicitly knows, that children need to be cared of by parents. Therefore they "substitute" caring parents. S/he realizes quickly, that non-fulfilment of needs is connected with the fact what the parents did not get (at the right time and from the right people) during their childhood. A so called process of parenting during childhood is being developed. Compassion can be considered for a source of this process (often lifelong) of a child with his/her parent, faith, in where the result of filling up the hole in role would be parent's ability to look after the child.

Pesso's theory of building up "stem self" is based on experience, where children, who fill the hole in role after the missing person, invest a part of self , [8]. Author further speaks about child's ability to become e.g. a virtual mother of his/her mother. Then the parent entity is located inside the child and can use a part of his/her life energy/power. The child does not take the energy in favour of self but of somebody else's. He/she becomes a particular supplier of needs for his/her parents. Yet the child does not usually lose hope that his/her needs that will be fulfilled. Therefore he/she more likely supports needed parents in hope and in order that parents "will grow up" and will be able to be as the child had wished and had implicitly expected to be.

Let us see the consequences of filling up the holes in roles. If these holes in roles have represent a long time character, then the child can start being in a role which s/he assumed, 
sticks to, will not want to give it up. The reason is that filling up holes in roles brings satisfaction to a certain point. The child has become early empathetic, compassionate with others, has strength, that helps adults. Consequently s/he will have decreased ability to accept support and help, rely on others and will feel well only in the role of a provider. A recipient's role will be for him in this case of necessary emergency connected with perception of loose of control, with resistance. It is seen that in psychotherapeutic and counselling practice, children who filled up the hole in role, unknowingly begin to consider themselves to be unlimitedly powerful and needful, as they were the only to be important and able to safe and solve problematic unfair situation. Pesso at this point speaks about so called a messianic gene. By disruption of natural limits of the child there is aggressive and creative force released which is perceived and integrated by the child as a part of his/her development. They are stored in the memory and furthermore used in the individual's life but at the expense of his/her own development. , [10]. Psychotherapeutic practice clearly demonstrates that experience with holes in roles negatively intervenes into formation of a healthy self-concept.

\section{Methodology}

\subsection{Purpose of the study}

The aim of research was to describe and analyse selected elements of education focused on processing of the holes in roles and to find out, how the helping workers work in the practice during direct work with the client.

\subsection{Research questions}

-What are the experiences of helping workers with the topic of clients' holes in roles?

-What elements of education do helping workers use during the direct work with the clients' topic of holes in roles?

\subsection{Research methods}

Considering the research objectives, the qualitative research strategy was chosen. A method of interview was used for data collecting. This technique was chosen since it leaves a certain space for creativity and possible addition of sub questions. , $[1,2]$. The data was analyses by utilising of elements of interpretative phenomenological interpretation (IPA). , [12]. We have interviewed 8 experienced PBSP therapists, in a gender-equal sample, within a semi-structured interview. The criterion for selection of respondents was a completed training in PBSP, at least 10 years of therapeutic practice and experience with the topic holes in roles in direct work with a client. Therefore this requirement of homogeneity of the sample has been complied. According to IPA's requirements we have considered each respondent for an expert in relationship to his/her experience, which we studied as a phenomenon, [11].

\section{Findings}

During the formation of the analysis we have gradually formulated the topics, which were depicting the essence of the phenomenon that presented the subject of our research as within IPA e.g. Willig [13] requires. We have monitored several phases: the transcript of the interviews has been repeatedly read, the text was provided by comments and notes, so 
called "emerging topics" have been formulated, subsequently we searched for the connections across the topics, then we searched for the formula across cases.

We found following experiences of helping workers with the topic of client's holes in roles. Bellow listed findings demonstrate further selected steps of the analysis provided identified topics have been accompanied by commentaries, direct respondents' quotes and our statements. Results have been structured according to the main topics, including reflection of relations among individual topics. See Table 1.

Table 1. Transcript sample of the interview $-2^{\text {nd }}$ phase - initial notes and comments, $3^{\text {rd }}$ phase - emerging topics

\begin{tabular}{lll}
\hline \multicolumn{1}{c}{ Notes and comments } & Interview transcript & Emerging topics \\
\hline $\begin{array}{l}\text { Least willingness = soon and a } \\
\text { lot in holes in roles }\end{array}$ & $\begin{array}{l}\text { The least willing for a therapeutic } \\
\text { change are people who had been } \\
\text { engaged in holes in roles very soon } \\
\text { and a lot. }\end{array}$ & $\begin{array}{l}\text { Feeling of uselessness in } \\
\text { the world without filling } \\
\text { up hole in role }\end{array}$ \\
$\begin{array}{l}\text { Identity is made by holes in } \\
\text { roles }\end{array}$ & $\begin{array}{l}\text { Their identity is somehow "made" } \\
\text { by that and they are no able to reflect } \\
\text { that by themselves. Sometimes they } \\
\text { say: "What would I do now, if my mum } \\
\text { had a partner, for what I would } \\
\text { actually be in the world?" }\end{array}$ & $\begin{array}{l}\text { Identity deformed by } \\
\text { holes in roles impedes }\end{array}$ \\
& $\begin{array}{l}\text { When the parent lives, so they do } \\
\text { not know what relation they should } \\
\text { really have. They are afraid of that } \\
\text { they would not have this "perforated" } \\
\text { relationship, thus they lose the contact, } \\
\text { suddenly feel cut off. This is a great } \\
\text { uncertainty and they are immediately } \\
\text { put back. }\end{array}$ & $\begin{array}{l}\text { Uncertainty: fear from } \\
\text { the loss of relationship } \\
\text { and contact with } \\
\text { significant others }\end{array}$ \\
& & $\begin{array}{l}\text { Inability to escape from } \\
\text { filling up the hole in role }\end{array}$ \\
& &
\end{tabular}

Sample of relationship (coherence) found throughout the topics is following (in the area of examples in Table 1). Feeling of uselessness in the world without filling up hole in role relates with a fear from the loss of relationship and contact with significant others. These relationships are in the connection with inability to escape from filling up the hole in role.

Following relationships confirming PBSP's theory origin and maintenance of holes in roles have been found across cases. There is a relationship between the time, when holes in roles started to emerge and individuals ability to reflect that. The fear from the loss of relationship and a contact with significant others contributes to insecurity and inability to escape from "stem self" (filling up the holes in roles). The mentioned fear and uncertainty are connected with anticipated feeling of uselessness in the world in case that the individual would stop filling the hole in the role.

Table 2. Sample of patterns emerging across cases - therapists'experiences

\begin{tabular}{l}
\hline Therapists' experience with the topic of a holes in roles \\
\hline Relationship to self: uncertainty and fear to be oneself \\
Relationship to significant others: fear from the loss of contact and relationship \\
Meaning of satisfaction and identification \\
Autoagression and a tendency "not to be" as a result of stem-self (filling up holes in roles) \\
\hline
\end{tabular}

Topics have appeared across the cases that connected experiences of PBSP therapists with topics holes in roles in direct work with clients. Individual's possibility perception to be him/herself is limited by filling up the hole in role $-\mathrm{s} /$ he became a care provider for 
significant others too early, there is a certain desire and experience for "childish" perception of self and at the same time there is fear of losing touch with the person needed. Briefly we list selected topics corresponding with the list in Table 2.

Firstly there was a significant topic of Importance of willingness to accept the client's change. Experience of helping workers points out at frequent reluctance of significant others to accept the change, which the client undertakes.

"Well, it depends how the partner is able to cease the change, or how the parents are able to cease the fact that the child is not always available."

"Maybe, this is what frightens people and they do not want to continue anymore, that they sacrifice again into their role."

"Relatives are afraid and sometimes threaten a bit, that they do not want them who they are starting to be, but often want them to be the "old ones". There is always some complementarity in that partnership..."

The topic of separation crisis has intermingled in the experience of therapists with the holes in roles- on one side there is the effort of the individual to live his/her life and on the other side perceived uncertainty and anxiety associated with that.

"... Separation crisis - they are leaving their family and looking for their life. Anxiety prevents them from finding their own life, which means oneself, because their self-concept is damaged because they had been so much engaged in the holes in roles that they could not capacity to recognize what they are really inside."

Holes in roles bring satisfaction. Significant others support the continuation of filling up holes in roles by appreciation etc. - therefore individual often struggles with his/her evaluation just on the basis of this model.

"...when I fill a hole in role brings me satisfaction... I have a good feeling that I so amazing - for somebody or for something."

Presence of holes in roles (emanating from the primary family) at traumatized clients it is connected with autoagression.

"... Autoagression - is very often shown that there is a hole in roles from the primary family. We often talk about clients who were not meant to be born. A hole in roles of a type of not accepted child. And they their whole childhood think and take on the hole in role that they will not live, they will not be here. Later on they are very often formed into victims - they choose violent partners, who do it for them "arrange"..."

Client's acceptance that fills the holes in role belongs to procedures, principles and elements of education, where PBSP therapists use while working with holes in roles. See Table 3 .

Table 3. Sample of patterns emerging across cases - procedures, principles, elements of PBSP education in practice

Procedures, principles and elements of PBSP education effective for work with holes in roles

Importance of client's acceptance

Meaning of education (strengthening of pilot functions)

Meaning of recapitulation

Meaning of controlled dissociation (the roles of movie observers)

Meaning of a slow procedure and "stepping"

Importance of forgiveness

Meaning of ideal figures' believability - work with movies

The experience includes essential importance of the meaning of positive approach towards the fact that the client fills the hole in role. 
“... Well, I speak about it positively - it is clear that a child looks after his/her parents, is enchanted by his/her amaziness, competence etc."

Practice implies the necessity of a slow procedure, "stepping" and continuous recapitulations, education and a continuous monitoring of ongoing review of understanding of the experience context with stem self (filling up the holes in roles). For the client, who perceives this great anger in this context, forgiveness has a great importance. Scenic symbolic procedure with the objective to meet client's needs is obvious in following phases. Movies are offered at the beginning. The client watches them as a spectator significant others, who are needed (who need to be cared of), are saturated with symbolic ideal parent figures. This act increases the client's receptivity to accept an ideal figure for him/herself. Another phase offers fulfilment of basis developmental needs on a symbolic level directly to the client him/herself -using interacting and ideal parent figures. This way the client's demand is satisfied, that the needs of his/her close ones must be fulfilled firstly. The work with movies guarantees that it happens so, without repeating the "old map" during therapeutic session (structure) the client is not the intermediator of needs for his/her loved ones.

Based on a treatment of holes in roles is possible to proceed the offer of ideal figure straight from a client. Client is already prepared for this "step", and is receptive to adopt ideal figures, which would fulfill his/her needs, which were in deficit until now. A new memory occurs, a new alternative client's memory record, a new map...

\section{Conclusions}

The education of counsellors and therapists who deal with the topic of holes in roles in the practice involves a long-term and a systematic training of specific work with the use of symbolic ideal figures.

We found out that the topic of holes in roles is frequent, complicated for processing even from the reason of unaccepting positive results of the client's environment. The topic is necessary to be processed by several steps. The client's life story plays an important role, especially significant others, who needed his/her care. Their needs are satisfied by utilising ideal symbolic figures in i.e. movies. Then it is possible to saturate client's unmet needs.

This article reports results of the project Specific research realized under the name "Využití scénicko-symbolické práce v poradenské praxi (s akcentem k tématu Holes in Roles)" ["The use of scenic symbolic work in counselling practice (with an accent to topic of holes in roles)"] at the Faculty of Education at the University of Hradec Králové in 2015.

\section{References}

1. Hendl, J., Kvalitativní výzkum: základní teorie, metody a aplikace [Qualitative research: basic theory, methods and applications]. Praha: Portál, (2008).

2. Miovský, M., Kvalitativní prŕstup a metody v psychologickém výzkumu [Qualitative approach and methods in psychological research]. Praha: Grada, (2006).

3. Norcross, J., \& Prochaska, J., Psychoterapeutické systémy [Psychotherapeutic Systems]. Praha: Grada, (1999).

4. Perquin, L., A specialization in Psychotherapy. In A. Pesso \& L. Perquin (Eds.), Capita selecta Pesso Boyden system psychomotor therapy. Amsterdam: [S.N.], (1997).

5. Pesso, A., Introduction to Pesso System/Psychomotor. Available from: http//www.pbsp.com, (1984). 
6. Pesso, A., Working with Sucidal Clients. In A. Pesso \& Crandell, J. (Eds.). Moving Psychotherapy. Theory and application of Pesso Boyden System Psychomotor therapy. Cambridge: Brookline Books, (1991).

7. Pesso, A., In Ch. Caldwell Getting in Touch: A Guide to Body-Centered Therapies. Wheaton: Publishing House, (1997).

8. Pesso, A., Holes in roles. Available from: http://www.pbsp.com/training/ holes in_roles $1 . h t m /,(2003)$.

9. Pesso, A., Filling the Holes in Roles of the Past, with the Right People at the Right Time. Available from http://www.pbsp.com, (2006).

10. Pesso, A., Boyden-Pesso, D., \& Vrtbovská, P., Úvod do Pesso Boyden system psychomotor [Introduction to Pesso Boyden System Psychomotor]. Tišnov: SCAN, (2009).

11. Smith, J., A., Flowers, P., \& Larkin, M., Interpretative phenomenological analysis: Theory, method and research. London: Sage Publications, (2009).

12. Řiháček, T., Čermák, I., \& Hytych, R., Kvalitativní analýza textů: čtyři př́ístupy [The qualitative analysis of texts: four approaches]. Brno: Masarykova Univerzita, (2013).

13. Willig, C., Introducting qualitative research in psychology: Adventures in theory and methods. Maidenhead: Open University Press, (2001). 